\title{
ISTRAŽIVANJE ČAGLJA (Canis aureus) U PARKU PRIRODE LONJSKO POLJE AKUSTIČNOM METODOM I METODOM FOTOZAMKI
}

\author{
RESEARCH OF GOLDEN JACKAL (Canis aureus) \\ IN THE NATURE PARK LONJSKO POLJE BY ACOUSTIC \\ AND CAMERA TRAPS METHODS
}

\author{
Goran GUŽVICA ${ }^{1}$ Monika PETKOVIĆ ${ }^{\text {, Marko AUGUSTINOVIĆ }}$, Lidija ŠVER ${ }^{2 *}$
}

\begin{abstract}
SAŽETAK
Naglo širenje područja obitavanja čaglja, ali i povećanje gustoće populacije, govori o visokom stupnju prilagodljivosti te vrste različitim stanišnim uvjetima. Prije 15-tak godina, pojava čaglja na području Parka prirode (PP) Lonjsko polje bila je sporadična, dok danas na tom području nedvojbeno egzistiraju teritorijalni čopori. U razdoblju od 2012. do 2015. godine provedeno je istraživanje s ciljem utvrđivanja broja i minimalne prosječne teritorijalne gustoće čopora čagljeva na području PP Lonjsko polje primjenom akustične metode i metode fotozamki.

Akustičnom metodom je procijenjeno da je na području PP Lonjsko polje u istraživanom razdoblju obitavalo 14 teritorijalnih čopora čagljeva, područje odaziva čagljeva bilo je od 186,30 do $214,50 \mathrm{~km}^{2}$ te se minimalna procijenjena gustoća čopora čagljeva kretala u rasponu od 0,65 do $0,75 \mathrm{na} 10 \mathrm{~km}^{2}$. U usporedbi s drugim istraživanim područjima u Hrvatskoj teritorijalna gustoća čopora čagljeva procijenjena akustičnom metodom na području PP Lonjsko polje je nešto manja, a jedan od mogućih razloga je činjenica da su određeni dijelovi PP Lonjsko polje u nekim razdobljima nedostupni čagljevima zbog poplava, što bi moglo imati utjecaj na njihovo korištenje prostora. U razdoblju od 2012. do 2015. godine metodom fotozamki je prikupljeno 437 (8,8 \%) fotografija/video isječaka na kojim su zabilježeni čagljevi. Nakon uklanjanja triplikata preostalo je 336 događaja čaglja odnosno fotografija/ video isječaka na kojima je ukupno zabilježeno 359 jedinki čaglja, bez mogućnosti determinacije na razini jedinke. Od ukupnog broja događaja, jedna jedinka je zabilježena u 94,64 \% događaja, a u 0,30 \% događaja zabilježen je najveći broj jedinki, odnosno 5 jedinki na istoj fotografiji/video isječku. Uporabom metode fotozamki je utvrđeno da je najveći stupanj aktivnosti čagljeva noću (73,51 \% od ukupnog broja događaja) i u sumrak (19,64 \%), ali su zabilježene i dnevne aktivnosti (6,85\%). Najveći broj događaja, zabilježen je između 3 i 5 sati. Tijekom dana, u četiri godine primjene metode fotozamki, nikada nije snimljena fotografija čaglja između 14 i 16 sati te 17 i 18 sati. Čagalj iskorištava resurse koje mu omogućavaju ljudske aktivnosti i naseljena područja. Međutim, ako na području obitavanja čaglja prevladavaju mozaici poljoprivrednih površina, gdje plijena ima u izobilju, ali je ograničena mogućnost dnevnog zaklona, čagljevi se pretežito kreću noću, što smanjuje rizik od susreta s ljudima.
\end{abstract}

KLJUČNE RIJEČI: čagalj, Canis aureus, brojnost i gustoća čopora, fotozamke, akustična metoda, PP Lonjsko polje

\footnotetext{
Dr. sc. Goran Gužvica, E-mail: gguzvica@oikon.hr; Marko Augustinović, mag. ing. silv., E-mail: maugustinović@oikon.hr; Monika Petković, mag. educ. biol. et chem., E-mail: mpetkovic@oikon.hr, OIKON d.o.o. - Institut za primijenjenu ekologiju, Trg senjskih uskoka 1-2, HR-10020 Zagreb, Hrvatska

${ }^{2}$ Izv. prof. dr. sc. Lidija Šver, Laboratorij za biologiju i genetiku mikroorganizama, Zavod za biokemijsko inženjerstvo, Prehrambeno-biotehnološki fakultet Sveučilišta u Zagrebu, Pierottijeva 6, HR-10000 Zagreb, Hrvatska; E-mail: Isver@pbf.hr

*Autor za korespodenciju (corresponding author): Lidija Šver, E-mail: Isver@pbf.hr
} 


\section{UVOD}

\section{INTRODUCTION}

Čagalj (Canis aureus Linné, 1758) je pripadnik porodice pasa (Canidae) kojeg karakterizira oportunizam i život u čoporu. U Europi postoje dvije populacije čagljeva, sredozemna i panonska od kojih su obje zastupljene u Hrvatskoj (Zachos i sur. 2009, Fabbri i sur. 2014, Rutkowski i sur. 2015, Anonymous 2015). U Hrvatskoj je zabilježen još u 15. stoljeću (Kryštufek i Tvrtković 1990) te se ubraja u autohtone vrste. U većem broju je poznat na jugoistoku Hrvatske i u sjevernoj Dalmaciji (Kryštufek i Tvrtković 1990, Kryštufek i sur. 1997, Krofel 2007, 2008, Bošković i sur. 2009). Između 50-ih i 70-ih godina prošloga stoljeća čagljevi su se počeli širiti u panonskom području te je populacija počela rasti (Kryštufek i sur. 1997, Bošković i sur. 2010, Šálek i sur. 2014, Trouwborst i sur. 2015, Anonymous, 2015). To podupire činjenica da u vrijeme spolnog sazrijevanja i odrastanja značajan broj jedinki dispergira iz čopora te se time povećava područje njegove rasprostranjenosti, što potvrđuju i genetske analize i raspon kretanja jedinke obilježene GPS ogrlicom (Moehlman 1987, Zachos i sur. 2009, Rutkowski i sur. 2015, Kapota i sur. 2016, Lanszki i sur. 2018). Tome doprinosi i sve veća dostupnost prikladnih staništa za čaglja koja bivaju oslobođena smanjenjem ili nestankom sivog vuka, Canis lupus (Giannatos 2004, Krofel i sur. 2017, Gužvica i sur. 2018). Stupanj istraženosti čaglja znanstvenim metodama u Hrvatskoj je relativno nizak, te rezultati ne pružaju mogućnost procjene brojnosti, posebice dinamike populacije čaglja. Većina dosadašnjih spoznaja temelji se na podacima iz sektora lovstva (Selanec i sur. 2011, Selanec i sur. 2012, Bošković i sur. 2013, Bezmalinović i sur. 2018). U posljednjih 15-tak godina populacija čaglja se povećala posebice u kontinetalnom dijelu Hrvatske (Selanec i sur. 2012, Bezmalinović i sur. 2018). Novija istraživanja praćenjem prijelaza životinja na zelenim mostovima preko autoceste pokazuju pojavnost i povećanje brojnosti čaglja u kontinentalnom, odnosno gorskom dijelu Hrvatske (Gužvica i sur. 2018). Na području Parka prirode (PP) Lonjsko polje unatrag desetak godina pojava čaglja bila je sporadična, dok danas na tom području nedvojbeno egzistiraju teritorijalni čopori. Cilj provedenog istraživanja bio je utvrđivanje broja i minimalne prosječne gustoće čopora čagljeva na području PP Lonjsko polje.

\section{MATERIJALI I METODE MATERIALS AND METHODS}

\section{Opis područja istraživanja - Study area}

Istraživanje je provođeno na području PP Lonjsko polje u okviru projekta „Praćenje utjecaja odlagališta otpada na populaciju čagljeva (Canis aureus) na području Parka prirode Lonjsko polje" u razdoblju od 2011. do 2015. godine. Terenska istraživanja provođena su od 2012. do 2015. godine.
PP Lonjsko polje smješten je u središnjem dijelu Republike Hrvatske, omeđen padinama Moslavačke gore i autocestom A3 Bregana-Zagreb-Slavonski Brod-Lipovac sa sjeverne, a rijekom Savom s južne strane. Nalazi se u aluvijalnoj ravnici središnjeg slijeva rijeke Save koja sa svojim pritocima i rukavcima stvara mozaike različitih staništa tipičnih za poplavljena područja. (Lončar 2006).

Sukladno Nacionalnoj klasifikaciji staništa na području Lonjskog polja se osim prirodnih i/ili do prirodnih staništa nalaze i antropogeno uvjetovana staništa na kojima prirodno obitavaju brojne biljne i životinjske svojte karakteristične za europsko-sjevernoameričku regiju. Najveću površinu Parka zauzimaju nizinske poplavne šume (otprilike $67,7 \%$ površine), potom antropogeno uvjetovani stanišni tipovi izgrađena i industrijska staništa te mozaici kultiviranih površina. Od drvenastih vrsta najzastupljenije su hrast lužnjak (Quercus robur) i obični grab (Carpinus betulus). Osim kopnenih staništa, PP Lonjsko polje prožeto je stalnim i povremenim vodama stajačicama, kanalima, povremenim vodotocima i tekućicama, koji mogu biti manje ili više obrasli vegetacijom, koji čine izvor bioraznolikosti takvih područja. Područje Lonjskog polja, protežući se preko 50650 ha, čini jedno je od najvećih nereguliranih poplavnih nizina u Europi, kompleks poplavnih šuma, močvara, livada, bara i riječnih rukavaca te poljoprivrednih površina. Fauna kukaca (Insecta), kao najveće skupine kopnenih beskralješnjaka, svojom biomasom čini značajni udio faune ovog područja, što je posljedica upravo kombinacije specifičnih stanišnih uvjeta ovoga područja. Na Lonjskom polju nalazimo 39 vrsta vretenaca, a fauna leptira iznimno je brojna te ponajviše vezana uz nitrofilne pašnjake i livade košanice (Gugić i sur. 2008). Tu obitava i više od $70 \%$ svih vrsta ptica zabilježenih u Hrvatskoj, unatoč tomu što nema planinskih i mediteranskih vrsta. Zabilježeno je oko 250 vrsta ptica, od čega se 134 vrste ovdje i gnijezde (Gugić i sur. 2008).

Od vrsta sisavaca na području Parka prisutne su vrste vezane uz vodena staništa, vidra (Lutra lutra), vodena rovka (Neomys fodiens), vodeni voluhar (Arvicola terrestris) i dabar (Castor fiber), kao i vrste vezane isključivo za kopnena staništa, poput 14 vrsta malih sisavaca kojima stanište predstavljaju poplavne šume hrasta lužnjaka (riđa voluharica (Clethrionomys glareolus) i šumski miš (Apodemus flavicollis) od glodavaca te šumska rovka (Sorex araneus) od kukcojeda, divlja svinja (Sus scrofa), obična srna (Capreolus capreolus) kao i vrlo stabilna populacija običnog jelena (Cervus elaphus)) (Gugić i sur. 2008).

Temeljna grana privređivanja lokalnog pučanstva na području Parka je poljoprivreda, a unutar poljoprivrede stočarska proizvodnja organizirana kao tradicionalna ekstenzivna proizvodnja (pašarenje, žirenje, košnja) koja također doprinosi specifičnosti staničnih uvjeta. Krupna stoka je na pašnjacima cijelo ljeto do kasne jeseni ili do novih poplava 
u listopadu i studenom (Gugić i sur. 2008). Na pašnjacima se odvija i ispaša autohtonih rasa svinja, u hrastovim šumama i šumama poljskog jasena. Pod utjecajem tradicionalnog stočarstva formirani su tzv. šumski otoci koji su na pašnjacima ostavljeni kao sjenovita područja za zaklon krupne stoke te poljski putevi koje stočari dnevno koriste za tjeranje stoke na ispašu.

Prema Boškovići suradnicima (2009), čagalj se na lovištima ponajprije hrani lešinama i otpacima, ali su mu u prehrani vrlo zastupljeni i mali glodavci, čije su populacije na Lonjskom polju vrlo raznolike i brojne upravo zbog prisutnosti velikih poljoprivrednih površina i travnjaka. Također, prema Radović i Kovačić (2010) vrlo važnu ulogu u prehrani čaglja osim sisavaca imaju i insekti i ptice, uključujući i ptičja jaja, koji su kao izvor hrane na području Lonjskog polja vrlo dostupni.

\section{Akustična metoda - Acoustic method}

Akustična metoda (Giannatos i sur. 2005, Krofel 2007, 2008) provodila se radi procjene broja i gustoće teritorijalnih čopora čagljeva u PP Lonjsko polje. Područje istraživanja podijeljeno je na kvadrante veličine $2 \times 2 \mathrm{~km}$. Površina od $4 \mathrm{~km}^{2}$, čini prosječnu veličinu životnog prostora (home range) čopora čaglja na području Lonjskog polja. Procjena veličine životnog prostora dobivena je prema rezultatima telemetrijskog praćenja jedinke čaglja obilježene GPS ogrlicom koje je također provedeno u sklopu ovog projekta $\left(\mathrm{MCP}=5 \mathrm{~km}^{2}, \mathrm{KDE}=3 \mathrm{~km}^{2}\right.$, neobjavljeni podaci) te temeljem objavljenih literaturnih podataka (Giannatos 2004, Rotem i sur. 2011). Unutar svakog kvadrata odabrana je jedna ili više lokacija s kojih se emitirala snimka zavijanja čagljeva. Kao lokacije emitiranja zavijanja izabrana su mjesta s obzirom na specifične stanišne uvjete Lonjskog polja (dostupne lokacije), a na kojima je pozadinska buka (blizina glavnih cesta, naselja) bila minimalna. Zvuk zavijanja tri čaglja je emitiran u trajanju od 30 sekundi, nakon čega je uslijedila pauza u trajanju od 5 minuta. Ako se nije čuo odaziv uslijedilo je ponavljanje seta emitiranja i pauze do šest puta. Prema navodu Giannatos i suradnika (2005) samo teritorijalni čopori čagljeva odgovaraju na emitirano zavijanje. Akustična metoda provođena je na području Parka prirode Lonjsko polje, a odaziv je zabilježen na lokacijama prikazanim na Slici 1.

Procjena broja čopora napravljena je Point Cluster i Heatmap analizom u programu Q GIS 3.4. Formiran je raster veličine $2 \times 2 \mathrm{~km}$ i preklopljen s točkama odaziva čaglja. Vrijednost varijable „Distance“, odnosno „Radius“ u analizi Point Cluster i Heatmap metodom definirana je kao $2 \mathrm{~km}$ na osnovi navoda Giannatosa i sur. (2005) da je najveća udaljenost s koje čovjek može tijekom mirne noći bez vjetra i kiše čuti odaziv čaglja 1,8 do $2 \mathrm{~km}$ (radijus). Rezultati obje metode analize u kombinaciji s formiranim rasterom koji predstavlja veličinu prosječnog životnog prostora čaglja (home range) utvrđen je broj čopora. Potom je GIS analizom oko lokacije odaziva opisan buffer od 1,8 te $2 \mathrm{~km}$ te je tako izračunata efektivna površina $\left(\mathrm{r}^{2} \pi\right)$ za auditivni odgovor čagljeva koja iznosi između 10,18 i 12,57 km² (Krofel 2008). Funkcijom „Dissolve“ u sklopu alata „Geoproccesing Tools“ izračunata je ukupna efektivna površina na kojoj je utvrđen broj čopora.

Minimalna prosječna teritorijalna gustoća čopora čagljeva na $10 \mathrm{~km}^{2}$ izračunata je kao odnos broja čopora i ukupne površine odaziva čagljeva.

\section{Metoda fotozamki - Camera trapping method}

Digitalne fotozamke s pasivnim infracrvenim senzorom (PIR) i infracrvenom bljeskalicom (NoFlash, Cuddeback, Green Bay, WI, SAD; Ecotone, Gdynia, Poljska; Trophy Cam 2010, Bushnell, Overland Park, KS, SAD) postavljane su u blizini lokacija odaziva čagljeva utvrđenih akustičnom metodom ili na mjesta gdje se očekivalo pojavljivanje čagljeva, primjerice tamo gdje su nađeni izmeti ili tragovi. Fotozamke su bile programirane na snimanje ili jedne fotografije i 30 sekundi video isječka ili tri uzastopne fotografije. Tako je omogućeno prebrojavanje jedinki čaglja na prikupljenim fotografijama ili videozapisima. Fotozamke su bile aktivne kontinuirano tijekom dana i noći s odgodom od 1 minute između dva događaja. Senzor za detekciju pokreta bio je postavljen na visoku osjetljivost i na automatsko mijenjanje razine osjetljivosti za dan i noć. Snaga bljeskalice postavljena je na visoku (prilagođena na veću udaljenost). Ukupno je korišteno pet fotozamki koje su strateški periodički razmještane radi pokrivanja što većeg područja. Analizirane su snimljene fotografije i videozapisi te determinirane vrste životinja i određen broj jedinki. Za analizu prebrojavanja jedinki u čoporu, dnevno/noćne/sumračne te cirkadijalne aktivnosti čagljeva, od ukupnog broja snimljenih čagljeva po događaju, odnosno jednoj aktivaciji fotozamke prolaskom životinje, od triplikata ili fotografije i video isječka je izabrana samo jedna fotografija ili video isječak na kojoj je zabilježen najveći broj jedinki. Za analizu dnevno/noćne/sumračne i cirkadijalne aktivnosti, fotografije/video isječci su razvrstani prema datumu i vremenu snimanja na noćne (sat nakon zalaska sunca do sat prije izlaska sunca), dnevne (sat nakon izlaska sunca do sat prije zalaska sunca) i sumračne (sat prije i sat poslije izlaska i zalaska sunca) (Rockhill i sur. 2013). Vrijeme izlaska i zalaska sunca tijekom godine na području postavljenih fotozamki preuzeto je s web stranice http:// astrogeo.geoinfo.geof.hr/online_efemeride/sunrise_sunset/. Za potrebe usporedbe dnevnih/noćnih aktivnosti s dostupnim podacima iz literature, napravljena je i raspodjela događaja na dnevne i noćne prema količini svjetlosti, pri čemu su noćnim fotografijama smatrane crno-bijele fotografije, odnosno fotografije snimljene $u$ infracrvenom spektru. 
Za analizu normalne distribucije podataka broja događaja korišten je Shapiro-Wilk test normalnosti, koji je potvrdio odstupanje od normalne distribucije podataka. S obzirom da je analizom histograma utvrđen pomak svih varijabli u istom smjeru, primjenom Studentovog t-testa za dvije varijable (McDonald 2014) testirana je značajnost razlike u pojavnosti događaja s obzirom na doba dana. Također, prema literaturi očekivana distribucija aktivnosti (Pyškova i sur. 2016) testirana je primjenom G-testa. Za sve statističke analize korišten je program R 3.1.3.

\section{REZULTATI}

RESULTS

\section{Procjena broja i gustoće čopora akustičnom metodom - Estimation of territorial packs number and density by acoustic method}

Akustičnom metodom izvršena je procjena broja i gustoće teritorijalnih čopora čagljeva u PP Lonjsko polje (Slika 1).
Tijekom razdoblja istraživanja akustična metoda provedena je na ukupno 109 lokacija, a odaziv čagljeva zabilježen je na 74 lokacije $(67,9 \%)$. U većini slučajeva na mjestima gdje su bili prisutni čagljevi odaziv se čuo nakon prvog ili drugog emitiranja zvuka.

Iz rezultata dobivenih provođenjem akustične metode izračunata je minimalna prosječna teritorijalna gustoća čopora čagljeva na području Parka prirode Lonjsko polje. Područje odaziva čagljeva procijenjeno je na 186,30 do $214,50 \mathrm{~km}^{2}$, a Point Cluster i Heatmap analizom procijenjen broj čopora čagljeva na tom području je 14, iz čega proizlazi da je minimalna prosječna teritorijalna gustoća čopora čagljeva od 0,65 do 0,75 na $10 \mathrm{~km}^{2}$.

\section{Rezultati primjene metode fotozamki - Results of camera trapping}

U razdoblju od 2012. do 2015. godine tijekom kojega je provođena metoda fotozamki prikupljeno je ukupno 7332 fotografije od kojih na 2340 (31,9\%) nije uočljiva životi-

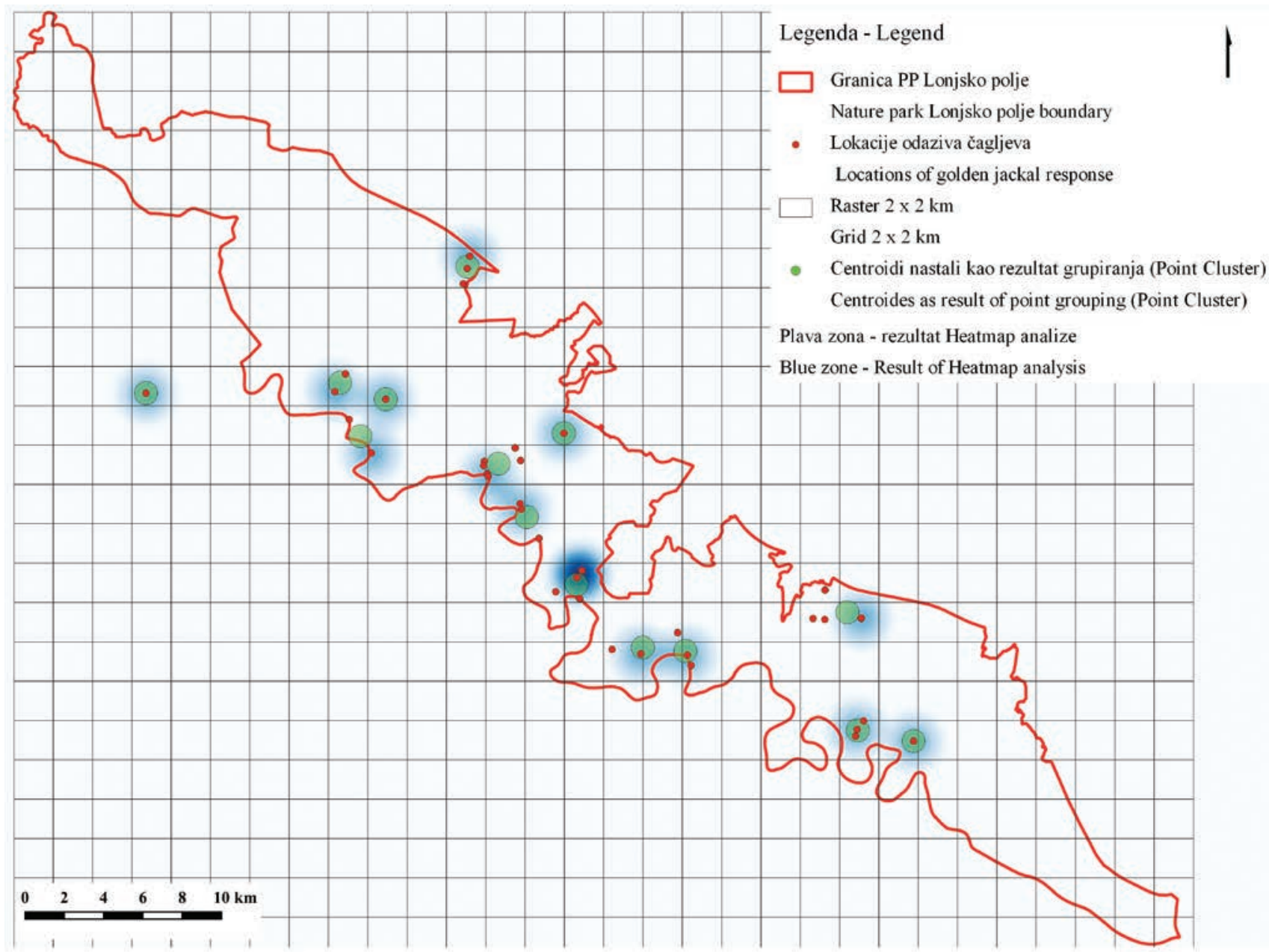

Slika 1. Lokacije odaziva čagljeva dobivene akustičnom metodom i rezultati procjene broja čopora Point Cluster i Heatmap analizom na području Parka prirode Lonjsko polje u razdoblju od 2012. do 2015. godine

Figure 1. Positions of golden jackals in Nature Park Lonjsko polje, estimated by acoustic method, and results of estimated number of packs derived form Point Cluster and Heatmap analysis, from 2012 to 2015 

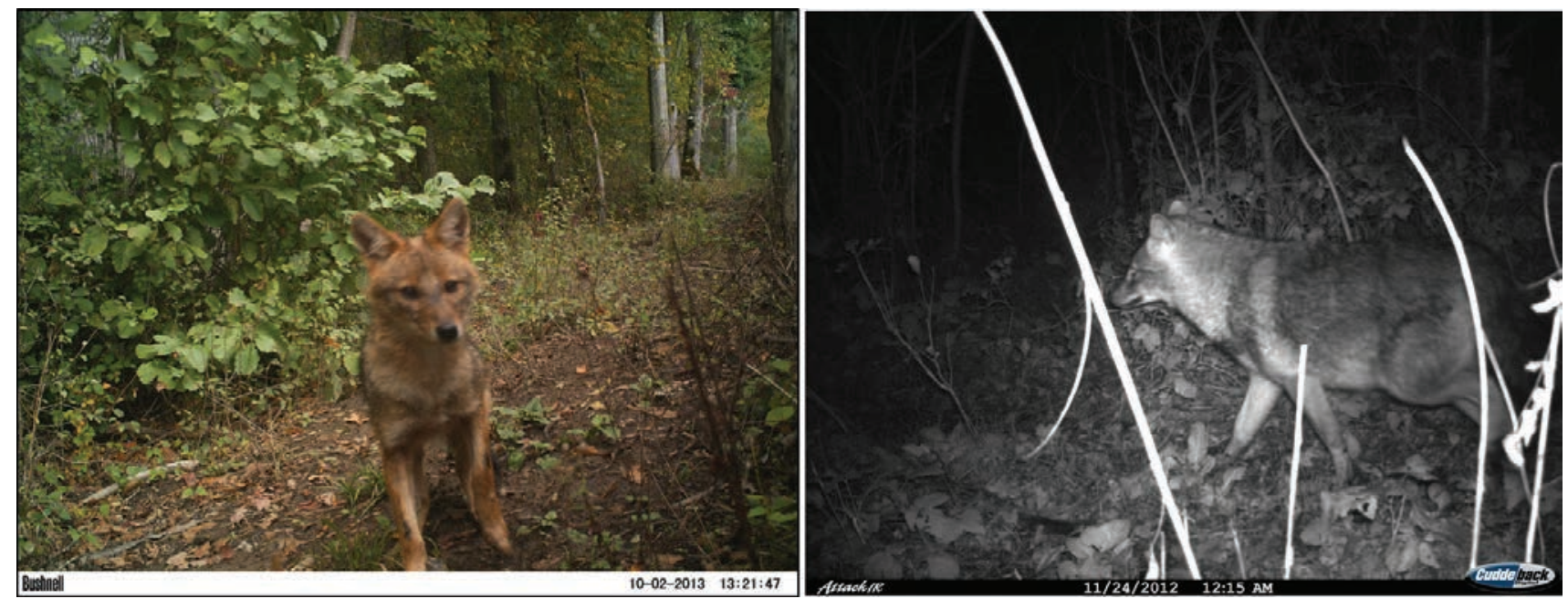

Slika 2. Fotografije čagljeva snimljenih u razdoblju od 2012. do 2015. godine metodom fotozamki na području Parka prirode Lonjsko polje Figure 2. Photographs of a golden jackal recorded in the Nature Park Lonjsko polje from 2012 to 2015 by camera trapping method

nja niti ikakvi tragovi kretanja ispred fotozamki. Od preostale 4992 fotografije na 437 ( $8,8 \%)$ su zabilježeni čagljevi (Slika 2), dok su na ostalim fotografijama zabilježene sljedeće vrste životinja: divlja svinja (Sus scrofa), srna obična (Capreolus capreolus), jelen obični (Cervus elaphus), lisica (Vulpes vulpes), kune (Martes spp.), divlja mačka (Felis silvestris), vidra (Lutra lutra), škanjac (Buteo buteo), fazan (Phasianus colchicus), sjenice (Parus spp.), miševi (Muridae) te domaće životinje i ljudi (Slika 3). Odredbom taksonomske pripadnosti i analizom podataka dobiven je opći pregled faune područja PP Lonjsko polje. Među najzastupljenijim vrstama divljih životinja su divlja svinja $(24,1 \%)$ i srna $(13,5 \%)$, a na $29,7 \%$ fotografija zabilježene su domaće životinje, ljudi i ljudske aktivnosti.
Nakon uklanjanja triplikata za daljnju analizu preostalo je 336 događaja čaglja odnosno fotografija ili video isječaka na kojim je ukupno zabilježeno 359 jedinki čaglja. S obzirom da u većini slučajeva na fotografijama nije moguće prepoznavanje čaglja na razini jedinke, od 359 snimljenih čagljeva nije moguće utvrditi koliko je puta snimljena ista jedinka.

Od ukupnog broja događaja, jedna jedinka je zabilježena u 94,64 \% događaja, a u 0,30 \% događaja zabilježen je najveći broj jedinki odnosno 5 jedinki na istoj fotografiji/video isječku (Tablica 1). Dakle, pet je minimalni broj jedinki u čoporu dobiven metodom fotozamki. Uporabom metode fotozamki utvrđeno je da je najveći stupanj aktivnosti čagljeva noću (73,51 \% od ukupnog broja događaja), ali su za-

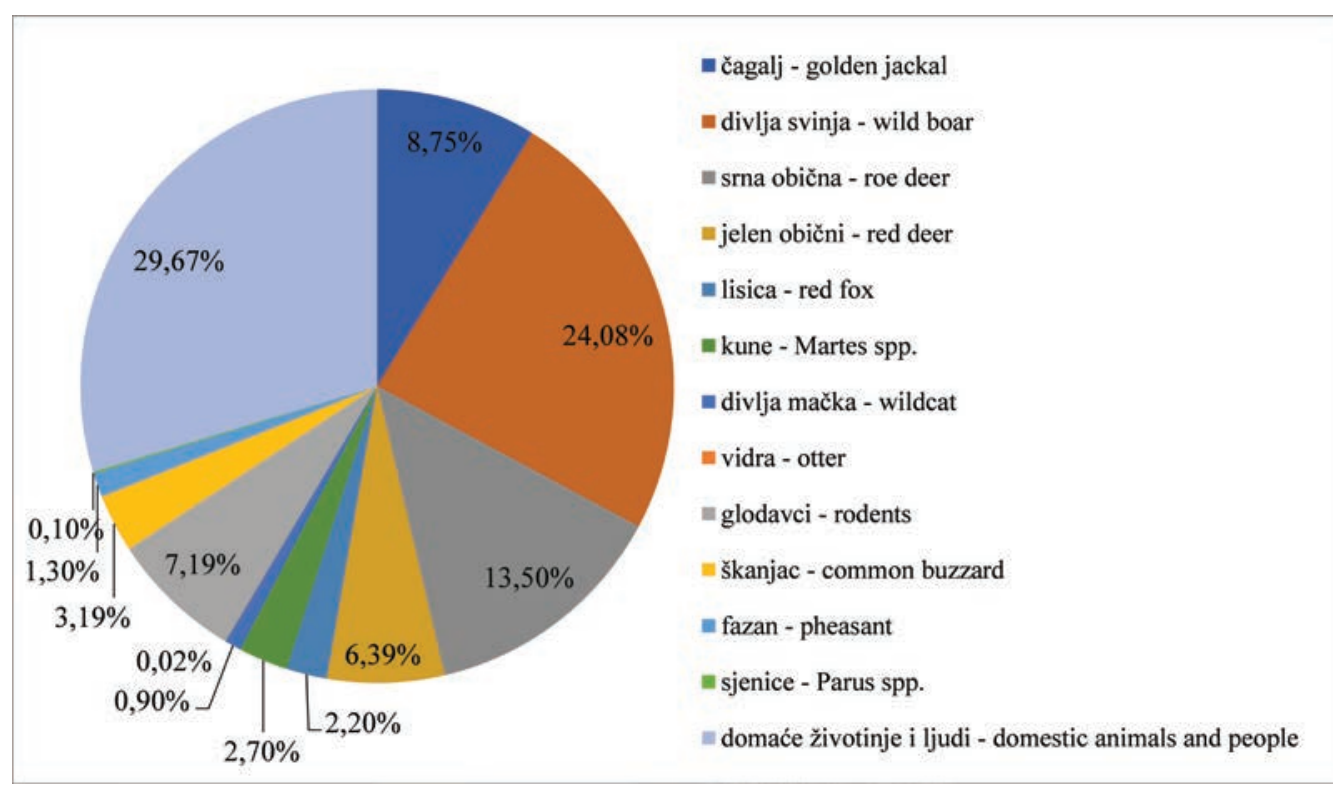

Slika 3. Postotni udio pojedinih vrsta zabilježenih metodom fotozamki na području PP Lonjsko polje u razdoblju od 2012. do 2015. godine Figure 3. The percentage of records for each species in data obtained by camera trapping method in the Nature Park Lonjsko polje from 2012 to 2015 
Tablica 1. Učestalost dnevnih, noćnih, sumračnih i ukupnih aktivnosti čaglja na području PP Lonjsko polje u razdoblju od 2012. do 2015. godine Table 1. Frequency of daily, night, twilight and total activity of golden jackal in the Nature Park "Lonjsko polje” from 2012 to 2015 obtained by camera trapping method

\begin{tabular}{|c|c|c|c|c|c|c|c|c|}
\hline \multirow{3}{*}{ broj jedinki na fotografiji/video isječku } & \multicolumn{4}{|c|}{ broj događaja } & \multicolumn{4}{|c|}{ učestalost događaja } \\
\hline & \multicolumn{4}{|c|}{ Number of events } & \multicolumn{4}{|c|}{ Frequency of events } \\
\hline & dan & noć & sumrak & ukupno & $\%$ dan & \% noć & $\%$ sumrak & \% ukupno \\
\hline Number of individuals per photo/video & Day & Night & Twilight & Total & \% Day & $\%$ Night & $\%$ Twilight & $\%$ Total \\
\hline 1 & 23 & 235 & 60 & 318 & 7,23 & 73,90 & 18,87 & 94,64 \\
\hline 2 & 0 & 10 & 5 & 15 & 0,00 & 66,67 & 33,33 & 4,46 \\
\hline 3 & 0 & 1 & 1 & 2 & 0,00 & 50,00 & 50,00 & 0,6 \\
\hline 4 & 0 & 0 & 0 & 0 & & & & 0 \\
\hline 5 & 0 & 1 & 0 & 1 & 0,00 & 100,00 & 0,00 & 0,3 \\
\hline $\begin{array}{c}\text { ukupno } \\
\text { Total }\end{array}$ & 23 & 247 & 66 & 336 & $6,85^{* *}$ & 73,51 & $19,64^{*}$ & 100 \\
\hline
\end{tabular}

${ }^{*} p<0,05$

$* * p<0,01$

bilježene i dnevne aktivnosti čagljeva (6,85 \%) te u sumrak $(19,64 \%)$ (Tablica 1). T-testom je utvrđena statistički značajna razlika u broju dnevnih i noćnih događaja $(\mathrm{p}<0,01)$ te broja događaja tijekom noći i sumraka $(\mathrm{p}<0,05)$. Na najvećem broju fotografija vidljiva je samo jedna jedinka čaglja (94,64 \% svih događaja). Tijekom dana, PIR senzor aktivirala je isključivo samo po jedna jedinka i to u 7,23\% događaja od ukupnog broja fotografija na kojima je snimljena samo jedna jedinka. Više jedinki na istom događaju zabilježeno je samo u sumrak (33,33 \% događaja sa zabilježene dvije jedinke te $50,00 \%$ događaja s tri jedinke) te noću ( $66,67 \%$ događaja sa zabilježene dvije jedinke i 50,00 \% događaja s tri jedinke). Maksimalni broj od pet jedinki tijekom istog događaja zabilježen je noću. Podjelom broja događaja samo na dnevne i noćne, utvrđeno je da je najveći stupanj aktivnosti čagljeva noću (92,56\% od ukupnog broja događaja), dok su dnevne aktivnosti čagljeva zabilježene u 7,44 \% događaja.
Najveći broj događaja, zabilježen je između 3 i 4 sata te između 4 i 5 sati (Slika 4). Tijekom dana, u četiri godine primjene metode fotozamki, nikada nije snimljena fotografija čaglja između 14 i 16 sati te 17 i 18 sati.

\section{RASPRAVA \\ DISCUSSION}

Akustična metoda provođena je kontinuirano na većem dijelu PP Lonjsko polje u razdoblju od 2012. do 2015. godine. Dobivene rezultate treba promatrati uvjetno, jer postoji vjerojatnost da se na više lokacija čuo odaziv jedinki koje pripadaju istom čoporu budući da se pojedine jedinke i dijelovi čopora povremeno i privremeno dispergiraju (Moehlman 1987, Zachos i sur. 2009, Kapota i sur. 2016, Lanszki i sur. 2018). Na osnovi analize podataka dobivenih akustičnom metodom je procijenjeno da je na području PP Lonjsko polje obitavalo 14 teritorijalnih čopora čagljeva.

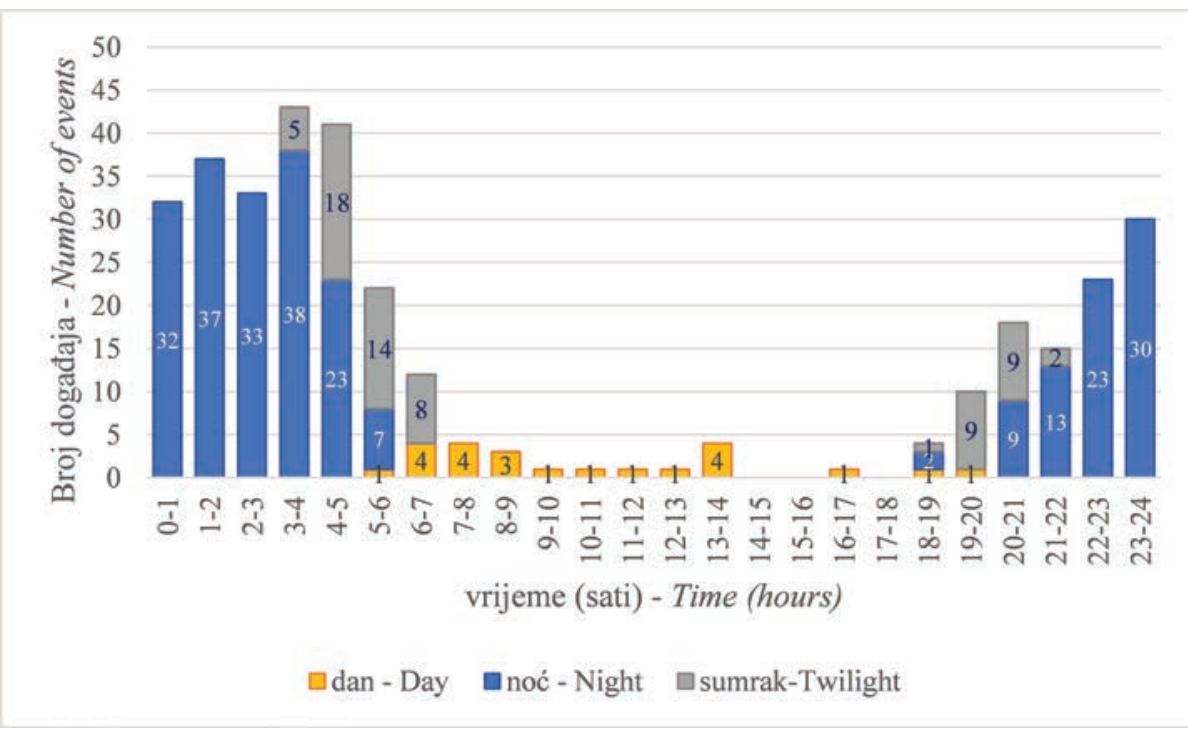

Slika 4. Raspodjela cirkadijalne aktivnosti čagljeva zabilježenih metodom fotozamki na području PP Lonjsko polje u razdoblju od 2012. do 2015. godine Figure 4. Distribution of the golden jackal circadian activity recorded by camera trapping method in the Nature Park Lonjsko polje from 2012 to 2015 
Prema metodi Giannatosa i suradnika (2005) područje odaziva čagljeva procijenjeno je na 186,30 do $214,50 \mathrm{~km}^{2}$ te je utvrđeno, s obzirom na procijenjeni broj čopora, da se minimalni procijenjeni broj teritorijalnih čopora čagljeva kretao u rasponu od 0,65 do 0,75 na $10 \mathrm{~km}^{2}$ na istraživanom području PP Lonjsko polje. Istraživanje gustoće populacije čaglja nizinskog područja Balkanskog poluotoka akustičnom metodom provedeno od 2007. do 2012. godine je pokazalo da je prosječni broj čopora 0,6 na $10 \mathrm{~km}^{2}$, ali s velikim rasponom od 0,1 do 1,1, a lokalno i do 4,8 na $10 \mathrm{~km}^{2}$ (Šálek i sur. 2014). Procijenjena gustoća teritorijalnih čopora čagljeva u sjevernom i središnjem dijelu Bosne i Hercegovine iznosi 0,26 čopora $/ 10 \mathrm{~km}^{2}$ te je njihova zastupljenost veća u sjevernom dijelu $\left(0,33\right.$ čopora $\left./ 10 \mathrm{~km}^{2}\right)$ što autori tumače imigracijom čaglja iz Hrvatske i, u manjoj mjeri, iz Srbije (Trbojević i sur. 2018). U usporedbi s drugim istraživanim područjima u Hrvatskoj teritorijalna gustoća čopora čagljeva procijenjena akustičnom metodom na području PP Lonjsko polje je gotovo ista s procijenjenom minimalnom prosječnom gustoćom čopora čagljeva na području Ravnih kotara $\left(0,61-0,75\right.$ na $\left.10 \mathrm{~km}^{2}\right)$, a manja od one na otoku Viru (1,15 na $\left.10 \mathrm{~km}^{2}\right)$ (Krofel, 2008). Jedan od mogućih razloga manje gustoće čagljeva u PP Lonjsko polje je činjenica da su određeni dijelovi PP Lonjsko polje (poplavne šume čine oko $60 \%$ površine) u nekim razdobljima nedostupni čagljevima zbog poplava, što bi moglo imati utjecaj na njihovo korištenje prostora. Tome u prilog govore i istraživanja Jaegera i suradnika (2007) koji su primijetili da čagljevi izbjegavaju poplavna područja.

Kontinuiranim provođenjem metode fotozamki na području PP Lonjsko polje u razdoblju od 2012. do 2015. godine prikupljene su 4992 fotografije na kojima su zabilježene divlje životinje, domaće životinje, ljudi i ljudske aktivnosti. Zastupljenost čaglja iznosila je 8,8 \% od ukupnog broja fotografija. Također, uporabom metode fotozamki je utvrđeno da je najveći stupanj aktivnosti čagljeva u noćnim satima, ali su zabilježene i dnevne i sumračne aktivnosti. Usporedbom rezultata cirkadijalne aktivnosti čagljeva s istraživanjima provedenim u Republici Češkoj uočen je visok stupanj sličnosti $u$ aktivnosti/neaktivnosti $u$ istim satima tijekom dana (Pyškova i sur . 2016). U njihovom istraživanju tijekom 10 mjeseci, uočen je gotovo isti obrazac ponašanja, odnosno nepojavljivanje čaglja na fotografijama/ video isječcima o razdoblju od 14 do 16 sati i od 17 do 18 sati. Međutim, u ovom istraživanju 92,56 \% zabilježenih fotografija/video isječaka bili su u noćnim satima u odnosu na istraživanje Pyškove i suradnika (2016) gdje je broj noćnih fotografija čaglja manji, odnosno $61 \%$ (G-test, $p<$ 0,0001). Čagljevi su vrlo prilagodljivi te veličina čopora ovisi o dostupnosti i distribuciji resursa (Macdonald 1979, Admasu i sur. 2004, Jaeger i sur. 2007, Rotem i sur. 2011). Čagalj iskorištava resurse koje mu omogućavaju ljudske aktivnosti i naseljena područja (koristi ceste, odlagališta komunalnog otpada i otpada nastalog lovnom aktivnosti kao izvor hrane), uključuje ih u svoje područje kretanja (Gupta i sur. 2014, Blumer 2015, Bošković i sur. 2010) te se broj jedinki u čoporu kreće od 10 do 20 jedinki (Macdonald 1979). Međutim, ako na području obitavanja čaglja prevladavaju mozaici poljoprivrednih površina, gdje plijena (glodavaca i domaće peradi) ima u izobilju, ali je ograničena mogućnost dnevnog zaklona, čagljevi žive samotnjački ili u parovima (Jaeger i sur. 2007). Korištenje staništa mozaika poljoprivrednih površina vjerojatno predstavlja kompromis između pristupa područjima bogatim hranom i povećanim rizikom od stradavanja zbog ljudskih aktivnosti (promet, lov, izravni progon). U tom slučaju, noćno kretanje smanjuje rizik od susreta s ljudima (Jaeger i sur. 2007, Rotem i sur., 2011). U ovom istraživanju, velika učestalost noćnih fotografija čagljeva u cirkadijalnoj aktivnosti vjerojatno je posljedica značajne zastupljenosti mozaika poljoprivrednih površina i vlažnih livada u PP Lonjsko polje.

U daljnjim istraživanjima nužno bi bilo primijeniti metodu prema Rowcliffe i suradnika (2008) koja omogućuje procjenu gustoće populacije pojedinih vrsta (uključujući i čaglja) bez determinacije na razini jedinke i predstavlja vrlo egzaktnu metodu za određivanje gustoće populacije. Prema toj metodi fotozamke trebale bi se rasporediti nasumičnim odabirom mjesta, međutim za provođenje te metode trebao bi znatno veći broj fotozamki, što u okviru ovog istraživanja nije bilo moguće provesti.

Osim navedenog, za preciznije određivanje brojnosti čopora, područja njihova kretanja (home range) i češćeg obitavanja (core area) te utvrđivanja njihove sklonosti pojedinim tipovima staništa, trebalo bi koristiti metodu GPS telemetrijskog praćenja više jedinki iz različitih čopora odnosno različitih dijelova PP Lonjsko polje.

\section{LITERATURA}

\section{REFERENCES}

- Admasu, E., S.J. Thirgood, A. Bekele, M.K. Laurenson, 2004: Spatial ecology of golden jackal in farmland in the Ethiopian Highlands. African Journal of Ecology, 42: 144-152.

- Anonymous 2015: Stručna podloga za utvrđivanje osnovnih odrednica obitavanja, statusa i smjernica gospodarenja čagljem (Canis aureus L.) u Republici Hrvatskoj. [e-dokument] Ministarstvo poljoprivrede i Sveučilište Josipa Jurja Strossmayera u Osijeku, Poljoprivredni fakultet u Osijeku, 102 str.

- Bezmalinović, H., T. Gomerčić, M. Sindičić, I. Selanec, 2018: Jackal population in Croatia continues to expand its distribution. U: P. Kružić, K. Caput Mihalić, S. Gottstein, D. Pavoković, M. Kučinić (ur.), 13th Croatian Biological Congress with International Participation, Hrvatsko biološko društvo, 318.-319., Poreč, Croatia

- Bošković, I., M. Šperanda, T. Florijančić, N. Šprem, S. Ozimec, D. Degmečić, D. Jelkić 2013: Dietary habits of the golden jackal (Canis aureus L.) in the eastern Croatia, Agriculturae Conspectus Scientificus 78, br. 3: 245-248. https://hrcak.srce.hr/106914 
- Bošković, I., T. Florijančić, K. Pintur, R. Beck, D. Jelkić, 2010: Hranidba čaglja (Canis aureus L.) u istočnoj Hrvatskoj. U: S. Marić, Z. Lončarić (ur.), 45th Croatian and 5th International Symposium on Agriculture, Josip Juraj Strossmayer University, Agriculture Faculty in Osijek, 968.-972., Opatija, Croatia

- Bošković, I., T. Florijanić, A. Beck, R. Beck, K. Pintur, A. Opačak, S. Ozimec, 2009: Preliminary diet research on golden jackal (Canis aureus aureus) in eastern Croatia. Krmiva, 51: 305-311.

- Bulmer, Lisa, 2015: The impact of anthropogenic disturbance on the behaviour and ecology of the golden jackal (Canis aureus). 10.13140/RG.2.1.4080.6009.

- Fabbri, E., R. Caniglia, A. Galov, H. Arbanasić, L. Lapini, I. Bošković, T. Florijančić, A. Vlasseva, A. Ahmed, R.L. Mirchev, E. Randi, 2014: Genetic structure and expansion of golden jackals (Canis aureus) in the north-western distribution range (Croatia and eastern Italian Alps). Conservation Genetics, 15, 187199.

- Giannatos, G., 2004. Conservation Action Plan for the golden jackal Canis aureus L. in Greece. WWF Greece, 47 str.

- Giannatos, G., Y. Marinos, P. Maragou, G. Catsadorakis, 2005: The status of the Golden Jackal (Canis aureus L.) in Greece. Belgian Journal of Zoology 135: 145-149.

- Gugić G., V. Hima, Z. Posavec, E. Bogović, D. Ivaštinović, 2008: Park prirode Lonjsko polje - živući krajobraz i poplavni ekosustav Srednje Posavine, Plan upravljanja, Javna ustanova Park prirode Lonjsko polje.

- Gupta, S., A. Sanyal, G. Saha, K. A. Ghosh, 2014: Diurnal Activity Pattern of Golden Jackal (Canis aureus Linn.) in an Urban Landscape of Kolkata, India. Proceedings of the Zoological Society, 1-6. 10.1007/s12595-014-0119-2.

- Gužvica, G., M. Petković, M. Augustinović, Z. Mesić, L. Šver, 2018: Analysis of golden jackal occurrence on green bridges as an indicator of their range expansion. U: S. D. Jelaska (ur.), 3rd Croatian Symposium on invasive species - with international participation, Croatian Ecological Society, 65.-65., Zagreb, Croatia

- Jaeger, M.M., E. Haque, P. Sultana, R.L. Bruggers, 2007: Daytime cover, diet and space-use of golden jackals (Canis aureus) in agro-ecosystems of Bangladesh. Mammalia, 71: 1-10.

- Kapota, D., A. Dolev, G. Bino, D. Yosha, A. Guter, R. King, D. Saltz, 2016: Determinants of emigration and their impact on survival during dispersal in fox and jackal populations. Scientific Reports, 6, 24021.

- Krofel, M. 2007: Golden jackals (Canis aureus L.) on the Pelješac Peninsula (Southern Dalmatia, Croatia). Natura Croatica, 16: 201-204.

- Krofel, M. 2008: Survey of golden jackals (Canis aureus L.) in Northern Dalmatia, Croatia: Preliminary results. Natura Croatica, 17: 259-264

- Krofel, M., G. Giannatos, D. Ćirović, S. Stoyanov, T.M. Newsome, 2017: Golden jackal expansion in Europe: a case of mesopredator release triggered by continent-wide wolf persecution? Hystrix, the Italian Journal of Mammalogy, 28: 9-15.

- Kryštufek, B., D. Murariu, C. Kurtonur, 1997: Present distribution of the golden jackal Canis aureus in the Balkans and adjacent regions. Mammal Review, 27: 109-114.

- Kryštufek, B., N., Tvrtković, 1990: Range expansion by Dalmatian jackal population in the 20th century (Canis aureus Linnaeus, 1758), Folia Zoologica 39: 291-296.

- Lanszki, J., G. Schally, M Heltai,. N. Ranc, 2018 Golden jackal expansion in Europe: First telemetry evidence of a natal dispersal. Mammalian Biology, 88: 81-84.
- Lončar, J. 2006: Park prirode Lonjsko polje. http://www.geografija.hr/hrvatska/park-prirode-lonjsko-polje/ Pristupljeno 10.03.2019.

- Macdonald, D.W. 1979: The flexible social system of the golden jackal, Canis aureus. Behavioral Ecology and Sociobiology, 5: 17-38.

- McDonald, J.H. 2014: Handbook of biological statistics (3rd Ed.). Sparky House Publishing, Baltimore, Maryland, 126-130.

- Moehlman, P.D. 1987: Social Organization in Jackals: The complex social system of jackals allows the successful rearing of very dependent young, American Scientist, 75: 366-375.

- Pyšková, K., D. Storch, I. Horáček, O. Kauzál, P. Pyšek, 2016: Golden jackal (Canis aureus) in the Czech Republic: the first record of a live animal and its long-term persistence in the colonized habitat. ZooKeys, 641: 151-163.

- Radović, A., D. Kovačić, 2010: Diet composition of the golden jackal (Canis aureus L.) on the Pelješac Peninsula, Dalmatia, Croatia. Periodicum biologorum, 112: 219 - 224.

- Rockhill, A.P., C. S. DePerno, R.A. Powell, 2013: The effect of illumination and time of day on movements of bobcats (Lynx rufus) ed M. Somers. PLoS ONE, 8, e69213.

- Rotem, G., H. Berger, R. King, P. Bar, D. Saltz, 2011: The effect of anthropogenic resources on the space-use patterns of golden jackals. Journal of Wildlife Management, 75: 132-136.

- Rowcliffe, J.M., J. Field, S.T. Turvey, C. Carbone, 2008: Estimating animal density using camera traps without the need for individual recognition. Journal of Applied Ecology, 45: 1228-1236.

- Rutkowski, R., M. Krofel, G. Giannatos, D. Ćirović, P. Mannil, A.M. Volokh, J. Lanszki, M. Heltai, L. Szabó, O.C. Banea, E. Yavruyan, V. Hayrapetyan, N. Kopaliani, A. Miliou, G.A. Tryfonopoulos, P. Lymberakis, A. Penezić, G. Pakeltyte, E. Suchecka, W. Bogdanowicz, 2015: A European concern? genetic structure and expansion of golden jackals (Canis aureus) in Europe and the caucasus. PLoS ONE, 10, 1-22.

- Selanec, I., B. Lauš, M. Sindičić, 2011: Golden jackal (Canis aureus) distribution in Croatia, U: C. Denys (ur.), VIth European Congress of Mammology, 60.-60., Paris, France

- Selanec, I., B. Lauš, M. Sindičić, S.D. Jelaska, 2012: GIS analysis of golden jackal (Canis aureus L.) distribution in Croatia, U: S.D. Jelaska, G.I.V. Klobučar, L. Šerić Jelaska, D. Leljak Levanić, Ž. Lukša (ur.) 11th Croatian Biological Congress with International Participation, Hrvatsko biološko društvo, 96.-97., Šibenik, Croatia

- Šálek, M., J. Červinka, O.C. Banea, M. Krofel, D. Ćirović, I. Selanec, A. Penezić, S. Grill, J. Riegert, 2014: Population densities and habitat use of the golden jackal (Canis aureus) in farmlands across the Balkan Peninsula. European Journal of Wildlife Research, 60: 193-200.

- Trbojević, I., T. Trbojević, D. Malešević, M. Krofel, 2018: The golden jackal (Canis aureus) in Bosnia and Herzegovina: density of territorial groups, population trend and distribution range. Mammal Research 63: 341-348.

- Trouwborst, A., M. Krofel, J.D.C. Linnell, 2015: Legal implications of range expansions in a terrestrial carnivore: the case of the golden jackal (Canis aureus) in Europe. Biodiversity and Conservation, 24: 2593-2610.

- Zachos, F.E., D. Ćirović, J. Kirschning, M. Otto, G.B. Hartl, B. Petersen, A.-C. Honnen, 2009: Genetic variability, differentiation, and founder effect in golden jackals (Canis aureus) from Serbia as revealed by mitochondrial DNA and nuclear microsatellite loci. Biochemical Genetics, 47: 241-250. 


\section{SUMMARY}

Golden jackal (Canis aureus Linné, 1758) belongs to the family Canidae, which is characterized by opportunism and life in a pack. The rapid dispersion of golden jackal, as well as the increase of population density, indicates a high degree of ability of this species to adjust to different habitat conditions. Only 15 years ago, the appearance of the golden jackal in the Lonjsko polje Nature Park (NP) was sporadic. Today, territorial packs in this area are widespread and confirmed.

Lonjsko Polje NP is located in the alluvial plain of the central Sava river basin, with mosaics of different habitats typical for flooded areas such as flooded forests, marshes, swamps, meadows and agricultural lands. Except insects, which make a significant proportion of fauna of this area, and mammal species related to aquatic and terrestrial habitats, more than $70 \%$ of all bird species recorded in Croatia inhabit NP Lonjsko polje. Small rodents, insects, birds and bird eggs, are highly represented in the diet of golden jackals.

During the research period from 2012 to 2015, the minimum number and minimum density of golden jackal territorial packs were estimated in the area of Lonjsko polje NP by acoustic and camera trap methods.

Using the acoustic (playback) method, we confirmed the existence of 14 territorial packs in Lonjsko polje NP (Figure 1). From each calling station a recorded group yip-howl was broadcasted, and the GPS locations where the jackal's response was heard, were recorded. For the calculation of the packs territory, around each recorded GPS location, the circle of 1.8 and $2 \mathrm{~km}$ radius was created. Outside of this radius human ear is not able to hear the sound of golden jackals howling. For the pack number estimation Point Cluster and Heatmap analysis in Q GIS 3.4. were used. By the use of the Q GIS function "Dissolve" in the Geoprocessing tools the total effective area of the response of the packs was calculated and it ranged from 186.30 to $214.50 \mathrm{~km}^{2}$. The minimum density of territorial packs per $10 \mathrm{~km}^{2}$ was calculated as a ratio of the number of packs and the total area of response of jackals and ranged from 0.65 to 0.75 packs per $10 \mathrm{~km}^{2}$. If compared to other areas in Croatia, the territorial density of the jackal packs estimated by the acoustic method in the area of NP Lonjsko Polje was slightly smaller. This is probably due to land unavailability caused by floods which impacts the pattern of space use of animals.

As part of this research, in the period from 2012 to 2015, five camera traps had been set and were afterwards periodically relocated to the places where the occurrence of golden jackals was expected. The golden jackal was recorded on 437 ( $8.8 \%$ from all photos with recorded animal or humans; Figure 3) photos or video clips. After the removal of the triplicates, 336 events of golden jackal photos or video clips were confirmed (Table 1). Without distinguishing individuals from each other, altogether, 359 individuals were recorded. In $94.64 \%$ of all events, only one individual was recorded. The largest number of individuals, 5 individuals on the same photo/video clip, was recorded in $0.30 \%$ of events. To analyze daily/night/twilight activity and circadian rhythm, photos/videos were sorted by date and time in to 3 categories: day, night and twilight (Figure 4). Student's T-test for two variables confirmed the highest activity of golden jackal during the night $(73.51 \%$ from all events, $\mathrm{p}<0.01)$ and twilight $(19.64 \%$, $\mathrm{p}<0.05)$. Daily activity was recorded as well (6.82\% from all events). The maximum number of events was recorded between 3 and $5 \mathrm{AM}$. During the day, in the four years of application of the camera trap method, a photo of the jackal was never taken between 2 and 4 PM and 5 and 6 PM. Golden jackal exploits the resources out coming from human activities, especially in the areas inhabited by humans. However, if mosaics of cultivated areas are a dominant habitat type, where prey is abundant but the possibility of daytime cover is limited, the jackal mostly move at night, reducing the risk of encountering humans. Hence, the high incidence of nocturnal photographs of golden jackal is probably the consequence of the prevailing human-dominated landscape, the presence of large areas of wet meadows in the Nature Park Lonjsko Polje and the increased risk of suffering due to human activities (traffic, hunting, direct persecution).

KEY WORDS: golden jackal, Canis aureus, number and packs density, camera traps, acoustic method, Lonjsko polje NP 